\title{
11 Domestic Politics and Chinese Participation in Transnational Climate Governance
}

\author{
Thomas Hale and Charles Roger
}

The efforts of China's central government to reduce greenhouse gas emissions are far more ambitious than those of other countries at a similar level of development, as well as those of, for example, the United States federal government. ${ }^{1}$ But they are also insufficient to stem the steep increase in greenhouse gasses (GHG) emitted by Chinese industry and Chinese consumers. China is the world's largest emitter of GHGs, accounting for almost a quarter of the world's total. Even on a per capita basis it now rivals the EU, and could overtake the US by the end of the decade. ${ }^{2}$

Climate change is, of course, the archetype of a global commons problem. But China's approach to the issue has been largely driven by domestic factors. Despite a relatively high-level of ambition at the national level, China has been reluctant to commit itself to a multilateral treaty establishing specific, verifiable, and binding emissions reductions targets. Its opposition to such targets, a minimum requirement for the developed countries, and particularly the United States, is commonly cited as the key blockage to efforts to negotiate a successor to the Kyoto Protocol. ${ }^{3}$

In this chapter we focus on Chinese participation in an area of the global climate regime outside of multilateral negotiations. While such talks have failed to deliver substantive reductions in emissions, and seem unlikely to in the near term, a host of projects and initiatives have arisen at the regional, national, and sub-national levels, and in the private and non-profit sectors, filling some of the "governance gap." Examples include reductions at the municipal level, voluntary reductions from firms, and various methodologies for pricing and trading carbon credits. Many of these actions link across borders to form transnational governance, which we 
understand as "the processes and institutions, formal and informal, whereby rules are created, compliance is elicited, and goods are provided in the pursuit of collective goals" when the actors involved are sub- and non-state actors from different countries. ${ }^{4}$

In the face of continuing multilateral gridlock, some observers have suggested that transnational climate governance (TCG) might hold some promise for mitigating the worst consequences of climate change. ${ }^{5}$ Ultimately, however, whether these non-multilateral actions are able to provide a meaningful complement, or even alternative to a "global deal," depends on whether or not they come to include a sizeable number of Chinese actors. Given China's vastand rising — share of global emissions, no system of transnational climate governance that fails to include a substantial portion of Chinese actors can hope to mitigate climate change on a significant scale. Yet, our understanding of Chinese actors' engagement with TCG remains limited, both empirically and theoretically.

On the empirical front, we have little understanding of the prevalence of TCG initiatives within China. Existing studies have examined Chinese involvement with individual TCG schemes, but offer no comprehensive picture of the scale, scope and robustness of this participation. ${ }^{6}$ At present, it is unclear what kinds of TCG initiatives Chinese actors participate in, and which actors have been involved. However, without answers to these questions, our ability to gauge the prospects of TCG within China, and more generally, remains limited.

On the theoretical front, we have little understanding of the factors that shape Chinese participation in TCG. Much of the existing literature on transnational governance has been developed within the context of Western liberal democracies, and in economies in which the state plays a less direct role in the economy than in emerging economies like China. ${ }^{7}$ Relatively less attention has been given to the politics of transnational governance in other types of states, 
leaving unanswered the question of how variation in domestic political institutions and statesociety relations conditions actors' engagement with transnational governance. Given that domestic political institutions are widely considered to shape participation in global governance generally, this lacuna must be filled if we are to explain existing patterns in transnational climate governance. ${ }^{8}$ China presents a crucial case in which to explore these dynamics.

Our chapter attempts to make progress on both fronts. Empirically, the chapter offers the first comprehensive study of China's participation in TCG. Scholars of transnational governance have recently pieced together a comprehensive picture of TCG at the global level, developing databases of TCG initiatives, which document the types of initiatives that exist and the different actors involved, as well as other data on issues and institutional features. ${ }^{9}$ For this chapter, we have adapted our own database to examine Chinese actors' engagement in TCG.

Working inductively from these findings, we tease out the assumptions existing approaches to TCG make regarding domestic political conditions, and consider how these might vary systematically. Several recent studies have demonstrated that features of domestic contexts help to explain why some transnational schemes (corporate certification schemes and public private partnerships) become widely adopted in certain states but not others. ${ }^{10}$ Building on these efforts, we seek to state in more general terms how the emergence and spread of transnational governance is affected by domestic conditions. Accounting for the context of "fragmented authoritarianism" in which Chinese actors find themselves is, we argue, essential for explaining the extent and character of their participation in different types of initiatives.

\section{Trends in Chinese participation in TCG}

Globally, TCG is a recent phenomenon. It emerged rather haltingly in the 1990s, when a few schemes became active around the time of the 1992 Earth Summit, such as Energie Cities 
(created in 1990) and the E8 (created in 1992). More schemes began to appear around the time of the 1997 Kyoto Protocol. TCG then "took-off."11 This trend is can be clearly seen in Figure 11.1, which is based on a database of 75 TCG initiatives that we have compiled and which confirms the findings of others. ${ }^{12}$ Between 1990 and 2000, the number of TCG schemes in the database grew from two to twelve schemes, and then to 75 by 2010 .

A large majority of those initiatives (53, or 77 percent) are active in countries in the developing world, and many involve Chinese participants. We find that just under half of all the initiatives in our database (33 in total, or roughly 44 percent) are active in China to some extent. Further, the number of initiatives active in China has grown quite significantly in a short period of time. As Figure 11.1 shows, from the first scheme in our global dataset in 1990, the first initiative in China appeared in 1999 and steadily grew from 2002 onward.

\section{<Figure 11.1 here>}

The initiatives in our dataset engage a broad range of activities, including informationsharing and networking (IN), standards and commitments (SC), financing- related activities (F); and operational activities (O) (see Figure 11.2). ${ }^{13} \mathrm{SC}$ schemes are those primarily involved in coding and implementing specific rules intended to reduce emissions by specifying, certifying and monitoring global best practices. IN schemes are those designed to build capacity by sharing knowledge, experiences and information, or which record emissions and commitments. Operational activities are those that perform governance services or provide collective goods, such as facilitating markets, supporting research and development, or helping to initiate other transnational partnerships. Finally, financing initiatives are a specific class of operational 
schemes that help to facilitate, direct, and provide funding to climate change-related projects and programs.

\section{< Figure 11.2 here>}

All of these kinds of TCG schemes are active in China to some extent, led by SC schemes (46 percent of the total in 2010). This is followed in order of importance by IN, $\mathrm{O}$ and $\mathrm{F}$ schemes, with shares of 28,16 and 10 percent, respectively. IN schemes were the first to appear in China, with the first becoming active in 2001. The first financing scheme (the World Bank's Prototype Carbon Fund) only appeared in 2005, when the first PCF-funded projects in China started, five years after the first financing initiative appears in our global dataset. The number of SC schemes grew four fold in 2007, quite late in our global dataset, and well after the initial increase in the total Chinese growth rate in 2004.

\section{< Figure 11.3 here>}

The emergence of different kinds of schemes (Figure 11.3) shows that 2007 stands out as a unique year in the China dataset, with not only the single largest increase in the number of SC schemes, but also the largest increase in the number of IN schemes. 2006, similarly, saw the largest single increase in the number of $\mathrm{O}$ schemes. Together, this suggests that the three-year period 2005-2007 was a crucial one for the growth of TCG in China, beginning with the first financing initiative and ending with the largest year of growth in SC schemes. Since then the 
growth rate tapers off in China and the rest of the world as well, although this is likely to be a statistical artefact.

$<$ Figure 11.4 here >

One of the most interesting trends is the difference between China and the rest of the world in terms of the kinds of actors targeted by TCG schemes (see Figure 11.4). In our global database we find that businesses are the largest category of target participant, followed by local governments, carbon market participants, governmental/sub-national governmental units and consumers, respectively. In China, on the other hand, there is a noticeable decrease in the share of businesses and local governments. Carbon market participants, by contrast, comprise a much larger share in China than in the global database - jumping from third to first place—as do governmental/sub-national governmental units.

Though TCG has grown rapidly in China, Chinese participation remains shallow and uneven. Carbon markets are by far the most successful area. Voluntary and compliance carbon markets have expanded significantly since 2005. The credits traded on the European Emissions Trading Scheme were worth some $\$ 120$ billion in 2010 and primary credits generated through the UNFCCC's Clean Development Mechanism were worth around $\$ 1.5$ billion. Voluntary carbon offset markets, though they had been strongly affected by the 2008-2009 downturn, came in at $\$ 1.2$ billion. And in each of these markets China occupies a dominant position. China is the largest source of certified emissions credits for the CDM, accounting for 60 percent of the total CERs issued, and 49 percent of all projects registered by the end of $2014 .{ }^{14}$ China has also been a significant source of the CDM credits used under the EU-ETS (since EU-ETS accepted CDM certified credits, although the EU has since restricted eligible CDM credits to those from least 
developed countries). China is less dominant in voluntary carbon offset markets yet still plays a major role, and there is evidence of a nascent voluntary market emerging in China, largely growing in response to the new pilot emissions trading schemes that have appeared and the National Development and Reform Commission's (NDRC) evolving policies on carbon offsetting. ${ }^{15}$

Carbon offset standards have grown in step as an essential dimension of such markets. In the case of compliance markets, the adoption of voluntary carbon standards such as the Gold Standard generally has a positive effect upon the price of carbon credits. Gold Standard certified carbon credits are sold at a premium of 5-25 percent over basic compliance credits, dependent upon project type, location and characteristics of the sale. ${ }^{16}$ In the case of voluntary carbon markets, offset standards play an even more important constitutive role by providing credible information to buyers about the quality of voluntary offsets and by establishing procedures for quantifying and, ultimately, pricing the emissions saved. Different carbon offset standards also allow buyers to purchase credits with additional "co-benefits," which can also favourably affect their price. As China has become more involved in each of these markets as a producer of both compliance and voluntary emissions credits, China has turned into a major adopter of carbonoffset standards. Today, around 27 percent of the voluntary carbon offset projects certified by the Verified Carbon Standard and 16 percent of those certified by the Gold Standard—two of the most prominent offset standards—are located in China (see Figure 11.5). China ranks as the second most significant user of both standards, behind only India and Turkey.

$<$ Figure 11.5 here > 
By contrast, transnational municipal networks and transnational corporate governance schemes, which are both central facets of TCG globally, have encountered major challenges in China. Consider first the role of local governments. Transnational municipal networks are a major area of TCG worldwide, and, as our database shows, 17 percent of the TCG initiatives currently active in China target local governments as participants. ${ }^{17}$ However, this figure is much lower than the world average. The experience of ICLEI, the oldest sustainability network of local governments, is exemplary. Its Cities for Climate Protection (CCP) program has had considerable success over the years, particularly in Australia and the United States. ${ }^{18}$ It has made numerous inroads across the developing world as well. However, while it is nominally active in China, ICLEI records only one Chinese member (Shenyang), a rate of participation far below many other large developing countries. ${ }^{19}$ There are 20 members in Brazil and 36 in India. And while ICLEI has numerous regional offices throughout Asia, there is none for China. Local officials in China have had little incentive to join networks like ICLEI because their benefits may be mismatched with local priorities. Involvement in networks that focus on reducing emissions may not help to bolster the position and resources of officials vis-a-vis other groups within the government and civic body that are more concerned with pressing local environmental issues. Other municipal networks with a strong emphasis on air pollution, such as the World Bank's Clean Air Initiative, have been more successful in China than those focusing exclusively on climate change.

Transnational initiatives focusing on corporate actors—-such as the UN Global Compact, Caring for Climate, the Carbon Neutral Network, the Carbon Disclosure Project (CDP), and the Global Reporting Initiative (GRI) — have encountered similar difficulties in China. Globally, businesses are the main kind of actor targeted by TCG schemes. But, in China, there are fewer 
schemes targeting businesses, and their results are mixed at best. In terms of uptake, the GRI may be the most successful of the corporate reporting initiatives in China. Chinese firms have submitted 278 CSR reports since the GRI's engagement in China first began in 2007. However, the quality of reporting has been highly uneven in China, with only 29 reports above an "A" application level; only 42 have been certified by GRI or a third party. Further, these raw figures overstate the real number of corporations involved, since many of the same firms have submitted reports in different years. The majority of the reports that received higher application levels also all came from the same small group of firms, largely in the service sector. All these figures are much lower than the world average. ${ }^{20}$

The Carbon Disclosure Project has also faced challenges in China. In 2011, only 11 of 100 Chinese companies invited to participate opted to answer the CDP's annual questionnaire, far below response levels elsewhere. ${ }^{21}$ Those that did were mainly from the banking industry. Trading and distribution companies, and firms from the hotel, restaurant, leisure, metals and mining, financial, construction, chemical, airline, and manufacturing uniformly did not respond. The distribution of participants in the most recent CDP questionnaire and in the GRI towards service sector firms and away from sectors such as construction, mining and chemicals is a trend plaguing other carbon reporting initiatives active in China. One effort to develop a common energy and emissions reporting framework specifically for China, the Energy and Climate Registry, which is based upon the Climate Registry and Greenhouse Gas Protocol, has so far found it difficult to attract participants in heavy industry. Only five Chinese companies have been recruited in nearly three years of operation, and they been unwilling to publicly disclose their involvement. ${ }^{22}$ 
The problem confronted by the developers of the Energy and Climate Registry, a voluntary reporting system that companies and cities can use to track and reduce their emissions, are symptomatic of transnational corporate governance schemes in China. Its developers have found that most are unwilling to take part mainly due to concerns about having to divulge sensitive technical data about production processes and business practices that may give an edge to competitors, especially when the reporting scheme originated from outside of China and is not directly supported by the key ministries in the Chinese government. ${ }^{23}$ Many companies have also reported that they are waiting to see what rules are made mandatory by the government before agreeing to voluntary disclosure. ${ }^{24} \mathrm{~A}$ more general issue has also been that Chinese businesses often see little value in addressing environmental issues. Except for a few leaders, such as Lenovo and Haier, "beyond compliance" environmental protection has been seen as too burdensome, and the value of corporate social responsibility has not been widely appreciated. In the absence of external pressures or price incentives, such as those for carbon offset standards, Chinese businesses have not been actively involved in TCG.

Finally, Chinese actors have mainly participated in TCG schemes as followers rather than leaders. Thus far Chinese actors have been involved in the initiation of only four schemes (the APP, Climate Savers, EcoPartnerships, and Methane to Markets). The vast majority of TCG schemes in China are therefore foreign in origin. And in all cases except one (Climate Savers, which included Lenovo as an initiating member), the initiating actor was the Chinese central government. This last point demonstrates a key finding of our study: China's domestic political structures condition the scope and nature of sub- and non-state actors' participation in TCG. Local government officials and private corporations in China are reluctant to join initiatives without knowing how such actions will fit with existing or anticipated governmental regulation. 
There is little willingness to take initiative without government approval. Moreover, the area in which Chinese participation in TCG is most robust—carbon markets—is, not coincidentally, an officially sanctioned program that is actively orchestrated by the National Development and Reform Commission and its provincial branches. ${ }^{25}$ NDRC officials have also been eager to develop expertise in carbon trading to support China's experiments with city- and province-level emissions trading schemes. In sum, while transnational governance is usually seen as a "bottom up" phenomenon, in China it often takes a government-led form.

\section{Transnational governance and domestic political factors-revised}

\section{expectations}

Domestic politics clearly affect participation in transnational governance. ${ }^{26}$

Bartley, a contributor to this volume, has shown how the nature of property rights and government dependence on industry affected the implementation of corporate certification schemes for forestry and apparel in Indonesia, strongly reducing the efficacy of transnational governance. ${ }^{27}$ The legacy of industrial policy impacted the implementation of the FSC and Responsible Care in Brazil and Argentina. ${ }^{28}$ Pro-environmental ministries have also been shown to encourage greater participation in transnational governance, showing that bureaucratic politics can work in TNG's favor. ${ }^{29}$

There are also some studies suggesting the same dynamics operate in China. Certification schemes such as ISO14001, an environmental management system standard, have been the most thoroughly explored. ${ }^{30}$ Most existing work has focused on firms, which have been seen as underparticipating in such voluntary programs. ${ }^{31}$ Two chief factors are emphasized to explain low participation: the weakness of civil society under China's authoritarian system and the lack of 
internalized environmental values within Chinese firms, their primary customers, and investors. Yet there are reasons to think that, while true, these arguments are too simple.

First, the "weak civil society" argument. In their examination of the participation of Pacific Rim companies in three transnational governance initiatives (the United Nations Global Compact, the Free Burma Campaign, and ISO 14001), Drezner and Lu conjecture that closed regimes, in which civil society is less influential, will see less firm participation in voluntary programs, since adoption of standards often depends on local advocacy. ${ }^{32}$ However, the Chinese authoritarian system's chilling effect on civil society is not absolute, especially not in the realm of environmental politics. The Beijing-based Friends of Nature, founded in 1994, is widely considered China's first environmental NGO. And, by 2004, the State Environmental Protection Agency estimated that some 2,000 NGOs existed. Today the figure is more than twice as large again. ${ }^{33}$ There is no doubt that the last 15 years have seen the emergence of a significant Chinese environmental movement. ${ }^{34}$

Chinese environmental NGOs often prefer subtle tactics—including research, information-sharing, public education, behind the scenes lobbying, and lawsuits—over more aggressive campaigning. ${ }^{35}$ Moreover, foreign environmental groups are highly active in Chinese politics, and have formed deep organizational and operational partnerships with local NGOs. As a result, Chinese environmental politics are relatively dynamic, even if they are ultimately bounded by the closed nature of the political system. We should therefore expect domestic and foreign civil society groups to be engaged in the kind of lobbying, corporate outreach, and locallevel activism that has been seen as a driver of transnational governance elsewhere. Indeed, TCG may be a particularly attractive strategy for NGOs precisely because of the constraints on more confrontational advocacy. 
The next issue is the "environmental values" question. Scholars frequently contend that Chinese corporations have internalized few environmental or social values, and face no pressure from domestic customers (who are not willing to spend more for greener products) or investors (who are often state-run banks). But this argument discounts some important nuances. Survey data consistently shows that environmental issues are important for much of the Chinese public, especially in urban areas, although it is true that this has yet to translate into a significant willingness to engage in consumer activism. Although socially responsible investment is minimal, some transnational governance programs, such as ISO14001, are widespread in China. ${ }^{36}$ This participation is largely driven by the need for Chinese firms to market to foreign companies that demand higher environmental standards (the "California effect") and by the diffusion of standards from foreign firms to their Chinese subsidiaries. ${ }^{37}$ Without these incentives, Chinese companies are seen as unlikely to join voluntary regulatory programs. ${ }^{38}$

A weak civil society and limited market demand may account for the low participation of Chinese actors in TCG, but it does not sufficiently explain the Chinese participation that we do observe. Moreover, since the arguments are directed mainly at TCG involving firms, they may not apply to other forms of TCG, such as transgovernmental networks or carbon markets. Explaining Chinese participation in different forms of transnational governance therefore requires attention to other aspects of Chinese domestic politics and state-market relations.

We argue that it is most useful to view transnational climate politics in China through the prism of "fragmented authoritarianism," which sees politics under the nominally centralized and authoritarian Chinese state as more pluralist than official institutions and popular perceptions suggest. The original concept was largely limited to intra-bureaucratic conflicts. ${ }^{39}$ More recently, however, Mertha has proposed that an ever- wider group of actors within China, including the 
media and NGOs, now possess unprecedented access to the policymaking process, as do commercial interests. ${ }^{40}$ Indeed, existing work on the domestic politics of climate change in China paints a picture of Chinese politics at their most pluralist.

Consider the intra-governmental divisions. Different units of the bureaucracy possess distinct policy goals, which inevitably come into conflict. The functional differentiation of China's ministries and sub-ministerial agencies make them accountable to different stakeholders, engender differing world views, and make an individual bureaucrat's success and chances for promotion linked to different—at times, incompatible—policy outcomes. China's national climate policies are an excellent demonstration of this phenomenon. Climate change was initially considered a scientific issue, and responsibility for it was first given to the politically weak China Meteorological Administration, an administrative unit under the State Council. But as the issue emerged on the international agenda, the Ministry of Foreign Affairs (MFA) began to take a dominant role in outlining climate policy. Though nominally under control of a committee representing four units of the bureaucracy, the MFA easily dominated the other more scientific bodies. However, as the issue became more connected to China's domestic political priorities at the end of 1990s and early 2000s, several reorganizations followed, the effect of which was to vastly increase the political salience of climate policy and put it under the control of the NDRC, the bureaucratic entity with broad responsibility for economic governance and the single most influential agency in domestic policymaking. The MFA, MEP, CMA, and the Ministry of Science and Technology (MOST) all act as vice-chairs of the inter-ministerial coordinating agency, each bringing distinctive priorities. The result is an institutionalized set of competing interests over Chinese climate policy, with economic development interests holding the dominant 
position. ${ }^{41}$ The result of this bargaining is a unified policy position that is generally accepted across the central government, even if it does not reflect a consensus position. ${ }^{42}$

The second major axis of contestation within the Chinese state is between the central government, the provinces, and local authorities. Because implementation must ultimately occur at the local level and Beijing possesses only limited resources to monitor and enforce implementation, provinces and more local authorities possess significant de facto power to veto centrally determined policies. Again, this dynamic is particularly pronounced in the environmental realm. ${ }^{43}$

In addition, actors outside the government have been increasingly vociferous, as discussed above. Fragmentation within the Chinese state creates greater "space" for contestation outside of it. A non-state interest group with no allies inside the state is unlikely to be seen as a legitimate actor in Chinese politics. But once an interest group can align with components of the Chinese state, its standing is considerably enhanced. The political space for contestation inside government and without is thus particularly large for issues, like climate change, where the interests of dominant groups are split. These opportunities apply to foreign groups as well, which is how foreign NGOs can serve as a major impetus behind Chinese climate policy. Scientific epistemic communities, Schroeder argues, played a key role in this process, transmitting both knowledge about climate change and norms regarding how China might respond to Chinese colleagues in government-backed research institutes and in the relevant ministries. These officials and ministries then became the leading advocates for pro-climate policies within the Chinese government. While international NGOs have been part of this process, they have relied less on the "naming and shaming" tactics common in other areas (such as human rights), and opted instead for informal lobbying and positive incentives such as awards. ${ }^{44}$ Linkages between 
foreign NGOs, local NGOs, and pro-climate officials in the national government can be quite close, creating effective transnational networks for climate advocacy. ${ }^{45}$ At the same time, Zhang Haibin argues that the role of foreign NGOs is often overstated, with analysts mistaking access to policymakers for influence over them. ${ }^{46}$

We argue that a fragmented authoritarianism perspective suggests a series of modifications to the usual pathways identified by scholars through which TCG is created. The fragmented nature of climate politics in China creates possibilities for TCG even as it conditions the form of TCG we should expect. Most theories of transnational governance ascribe to suband non-state actors a significant degree of political agency. Two assumptions lay at the core of this view. First, it assumes that sub- and non-state actors have independent preferences over policy. Yet when sub-national governments or bureaucratic actors are mere extensions of a national government, they cannot be understood to hold meaningfully independent preferences. We should therefore expect less transnational governance in centrally controlled polities, in polities where market actors are dominated by the state, and in polities with weak civil societies. Second, the bottom-up mechanism assumes that sub- and non-state actors seek to realize their preferences through political activity outside of lobbying the national government (such as by "naming and shaming" polluting corporations to improve their behavior, creating certification schemes, and taking unilateral action at the local level). This strategy requires capacity in terms of material resources and expertise to engage in political contestation, and a political context in which such actions are accepted as legitimate, with guaranteed rights to organize and exercise voice, constitutional or de facto authority over local policy choices. All else being equal, we should therefore expect more engagement in transnational governance when sub- and non-state 
actors are relatively autonomous and when they possess and are able to use political resources with which to pursue their objectives.

In China, then, two important modifications to the bottom up mechanisms may be required. First, a fragmented authoritarianism perspective suggests that we may need to re-think the nature of the actors who engage in bottom-up climate politics. The existing literature sees private firms, NGOs, and ambitious local governments as the primary creators of TCG. But in a political system like China's, in which many meaningful policy contests are resolved within the state-party apparatus, we can expect significant agency to lay with governmental actors, especially those at the national level. Even when private interests instigate TCG, they are likely to desire governmental support to increase their legitimacy, meaning that partnered governance arrangements will be relatively more common than purely private ones. Second, when the firms with the most capacity to affect climate change are state-owned, we should also expect intra-state bargaining, not private-private bargaining, to determine the success of TCG initiatives. While the literature has shown that private companies linked to export markets and FDI have been quick to adopt transnational governance, we should not expect similar behavior from electric utilities, construction firms, or the like. Naming-and-shaming will have little impact on state monopolies. Voluntary corporate programs will therefore likely receive little participation from Chinese actors.

This is why Chinese TCG is driven more strongly by government orchestration. ${ }^{47}$ In this case, the capacities of sub- and non-state actors to effect governance can be thought of as a tool the state would like to employ, but one it cannot simply order these actors to deploy. Again, there is a core assumption of political agency. However, there is also an assumption that the state lacks absolute authority to order the changes it seeks (or, more plausibly, lacks the legitimacy or 
political capital to attempt such "command and control" strategies), and must therefore rely on the gentler strategy of orchestration. As we have discussed elsewhere, orchestration offers a potentially powerful mechanism for ministries and local governments to employ when they cannot realize their goals through the national policymaking process. ${ }^{48} \mathrm{We}$ should therefore expect the more environmentally oriented parts of the Chinese bureaucracy to attempt to bring sub- and non-state actors into TCG via this mechanism.

In sum, then, we would expect the autonomy, capacity, and social context of actors-key components of the mechanisms through which TCG is created - to be strongly conditioned by the nature of the state. Prima facie, these considerations might lead us to expect China's centralized, authoritarian government and that large role the state plays in the economy to significantly curtail Chinese sub- and non-state actors' engagement in TCG. In fact, we argue that domestic conditions in China are in some ways more favorable to TCG than may be expected, and that participation in TCG can be even be quite strong when goals of TCG initiatives align with those of components of the state.

\section{Conclusion: prospects for TCG in China and in general}

Chinese actors are important players in TCG, and TCG, in turn, has had an important impact on Chinese climate policy. The nature of Chinese actors' participation, however, differs in some respects from conventional theoretical expectations. At the aggregate level, the composition of schemes active in China differs from global patterns. In China, entrepreneurial programs are less common, local governments have participated less in TCG than their counterparts, the central government has participated to a greater extent in TCG than elsewhere, and, largely as a result, carbon markets have been more important in China than elsewhere. 
These differences derive from the domestic political context in which Chinese sub- and non-state actors operate. Though the centralized, authoritarian political system and state-led economy dampen the agency of many potential TCG creators and actors, the relative pluralism that characterizes Chinese climate politics also increases the possibility and utility of TCG as a strategy. It is often the incentives and opportunity structures that the state creates that open up as a result of its fragmented nature, which determines the shape of TCG participation. As we have seen, TCG initiatives focusing on local governments have faced considerable challenges. Local officials have so far had little incentive to join networks like ICLEI, which over their twenty years of operation have acquired thousands of members elsewhere throughout the world. Corporate reporting initiatives, which have been an important form of governance in the domain of climate change, have been relatively less successful in China with strategic industries and when initiatives threaten to disclose sensitive information. Further, they have been more successful where the level of reporting is more flexible, as in the GRI. Yet, where the TCG initiatives complement activities engaged in by the state, as with various carbon market initiatives, participation can be quite considerable

These findings cast doubt on the hopes of TCG's more enthusiastic supporters that measures like corporate codes of conduct or city-level programs will have a large impact on China's growing emissions. Some of the kinds of initiatives that have been most common in the field of TCG, and highly effective in more liberal political contexts, face significant challenges without support from key players within the Chinese government. A major part of the problem is that the goals of some TCG schemes may have been mismatched with local priorities. Greater effort may therefore be needed in the future in order to create new schemes and adapt existing ones to make them more acceptable within the Chinese context, and to emphasize their co- 
benefits. However, shifts within the Chinese state itself on the issue of climate change may also augur well for some initiatives, especially those that focus on municipalities. As we noted above, changes in local officials' incentives as a result of the growing importance of local emissions and energy efficiency targets may widen the scope for such schemes in the future. The pilot carbon trading schemes currently being developed are also likely to further raise the incentives for participation,. Thus, while the domestic context in China has so far had, on balance, a dampening effect upon Chinese involvement in TCG, changes in this context — and the goals of the state, in particular-may make TCG more important in the future. 


\section{Figures}

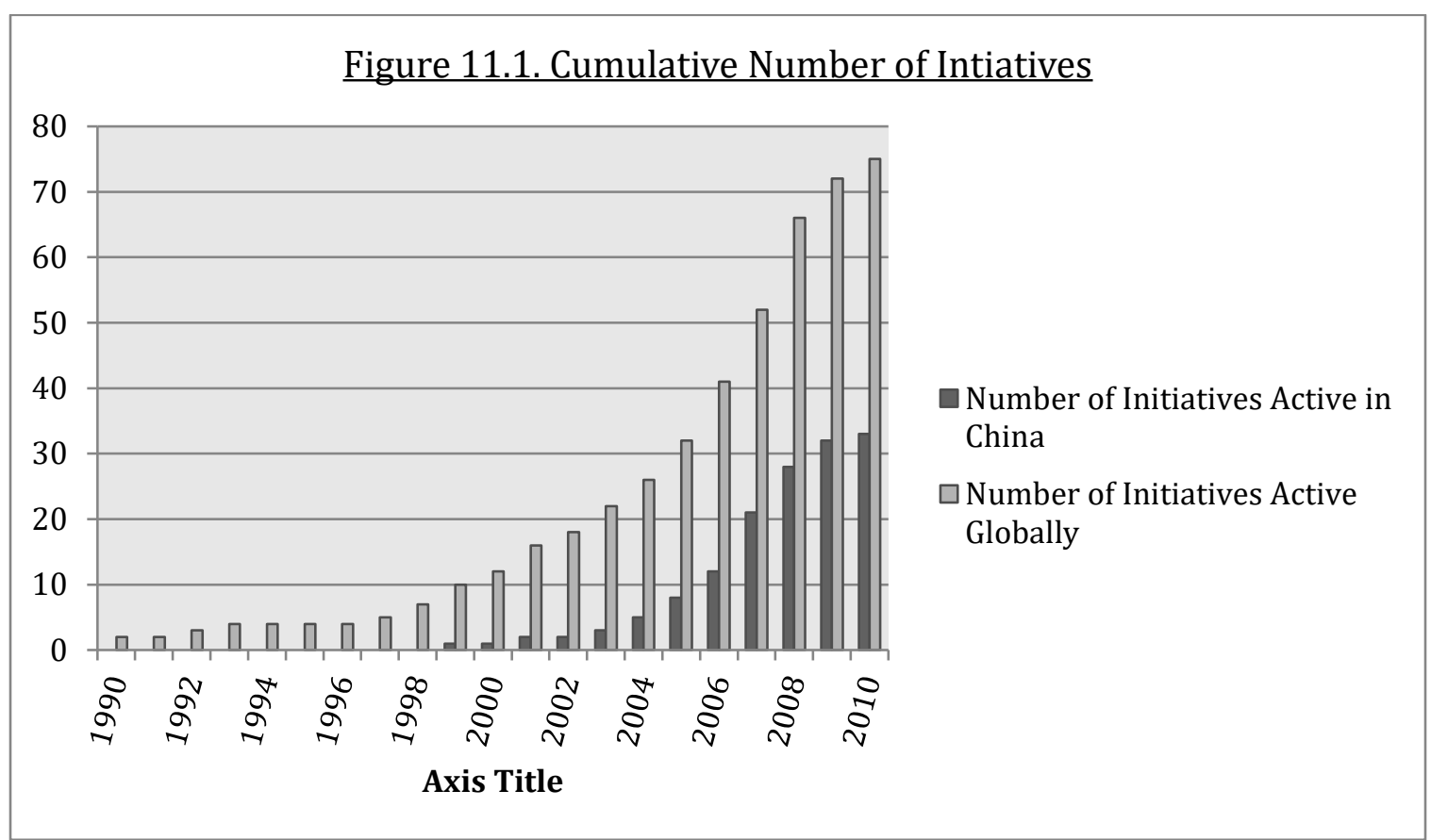

Source: Database developed by Thomas Hale and Charles Roger (2014). For detai Is, see "Coding the Transnational Climate Governance Database" available at: http://link.springer.com/article/10.1007/s11558-013-9174-0. For access, please contact the authors. 


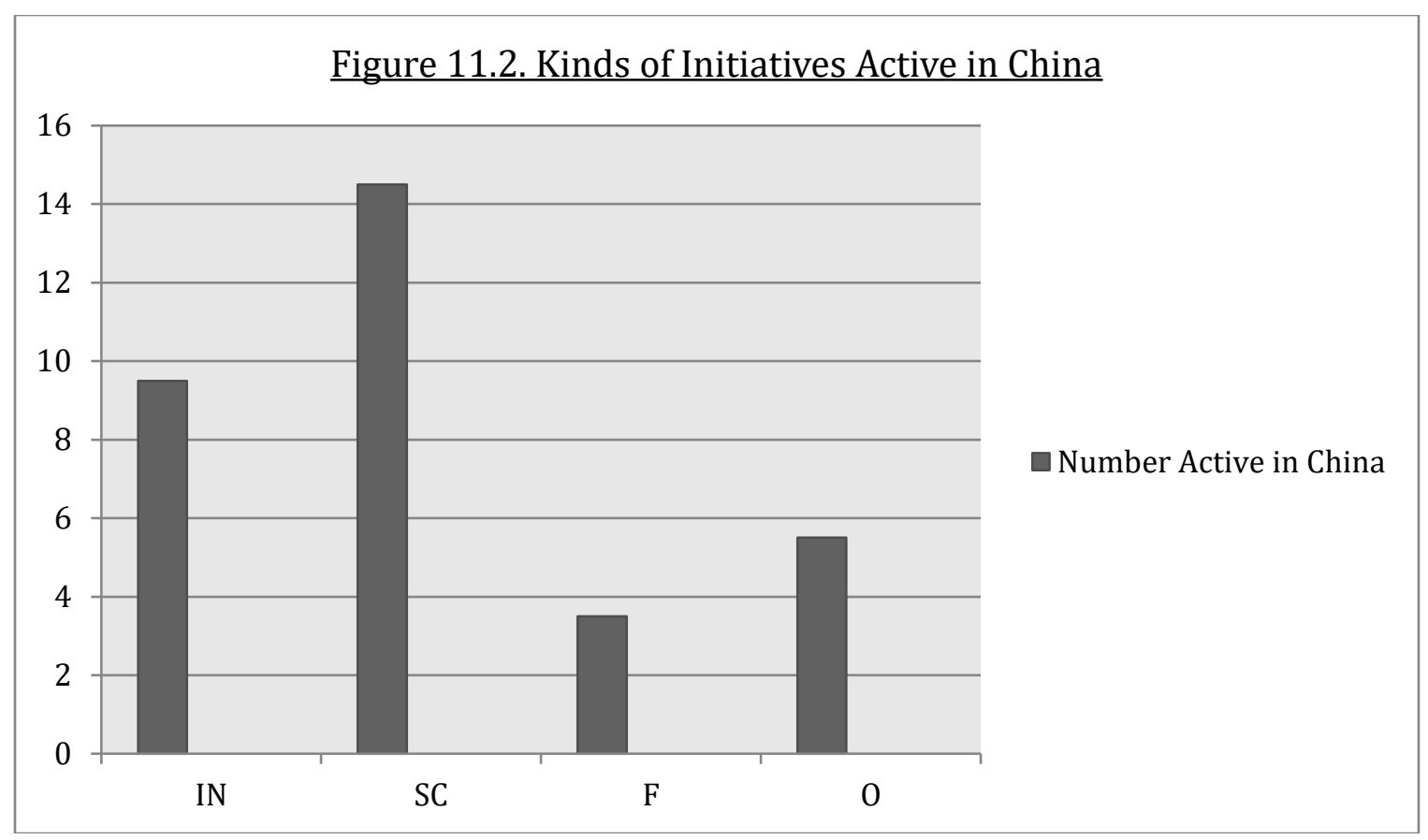




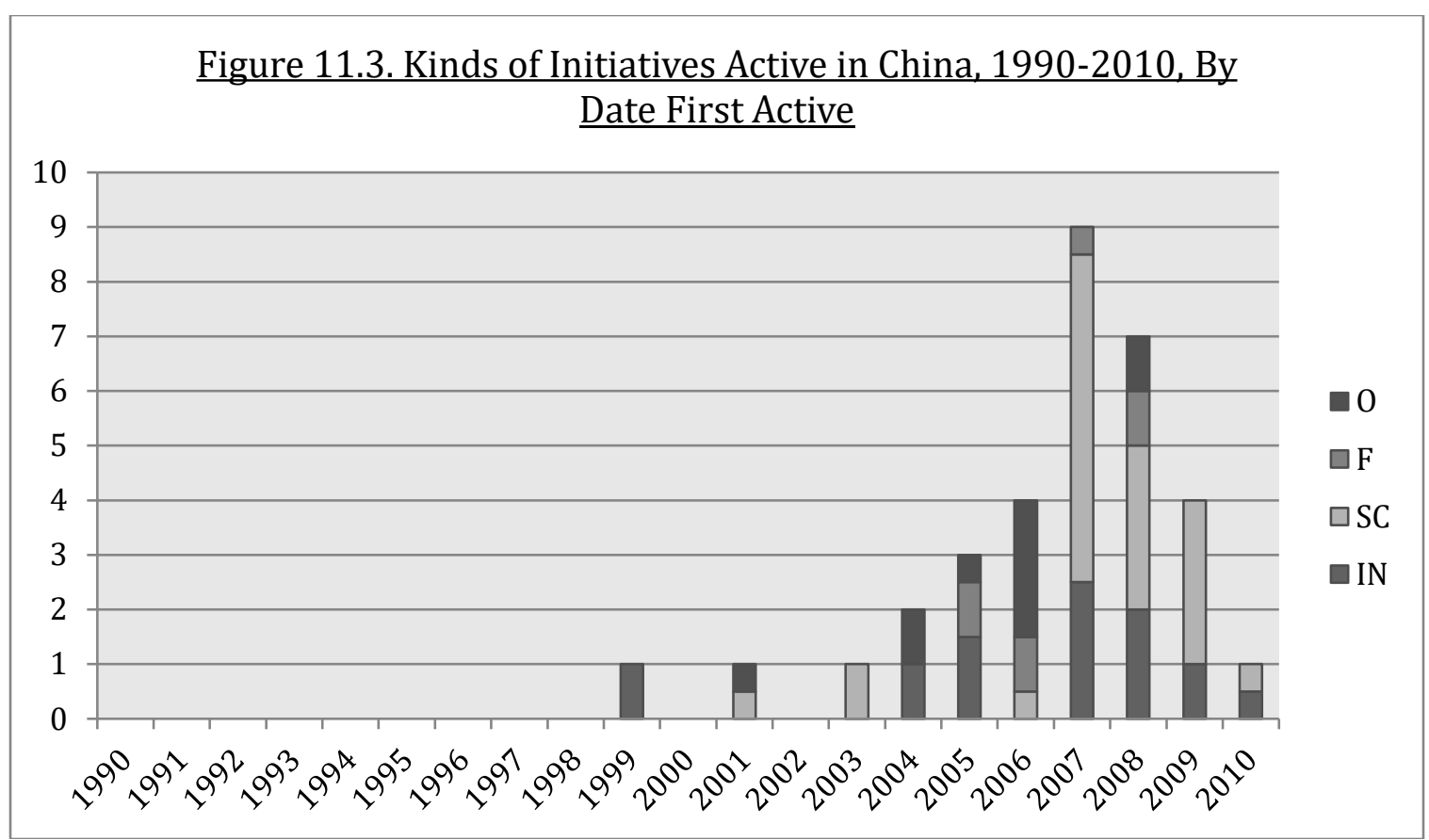




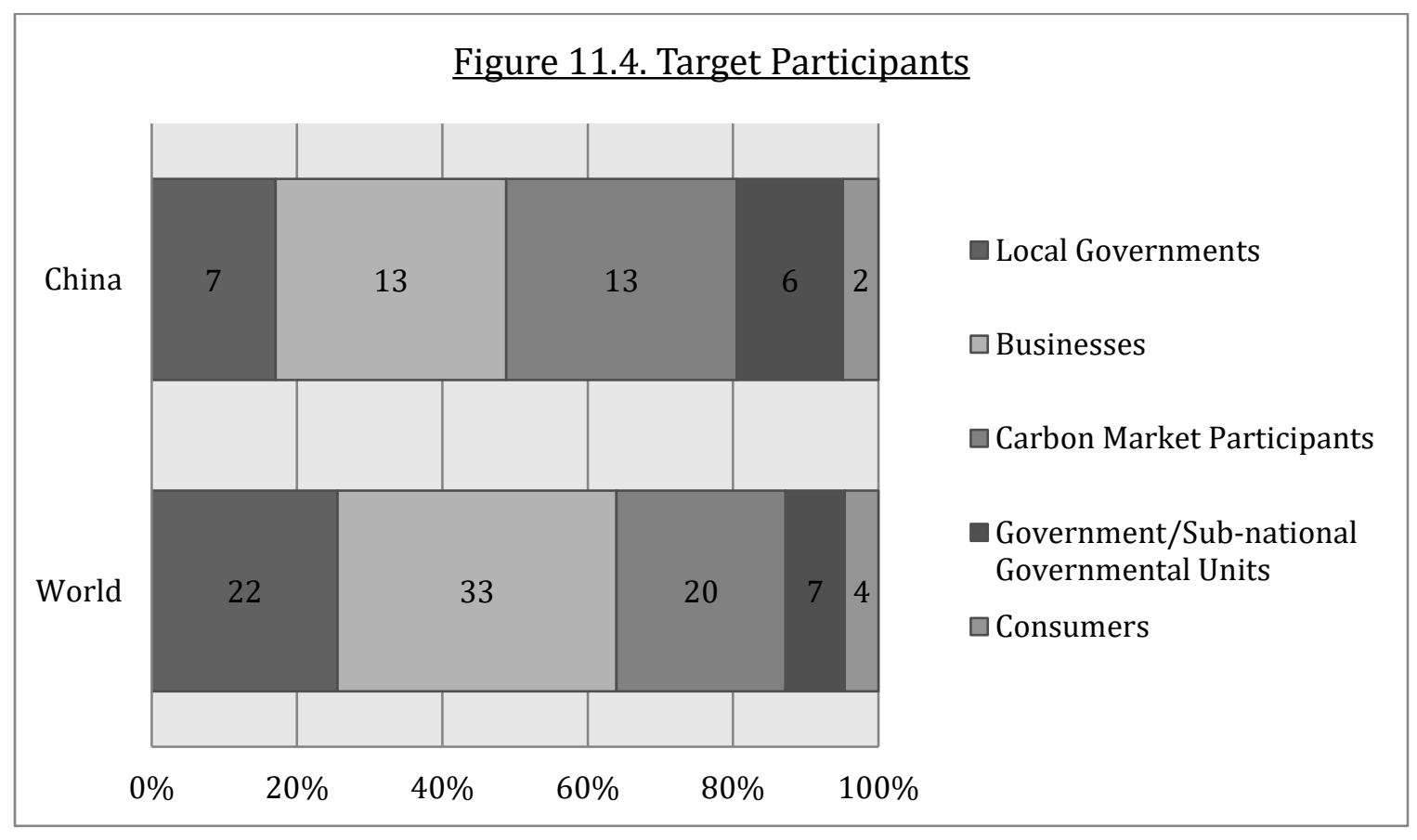




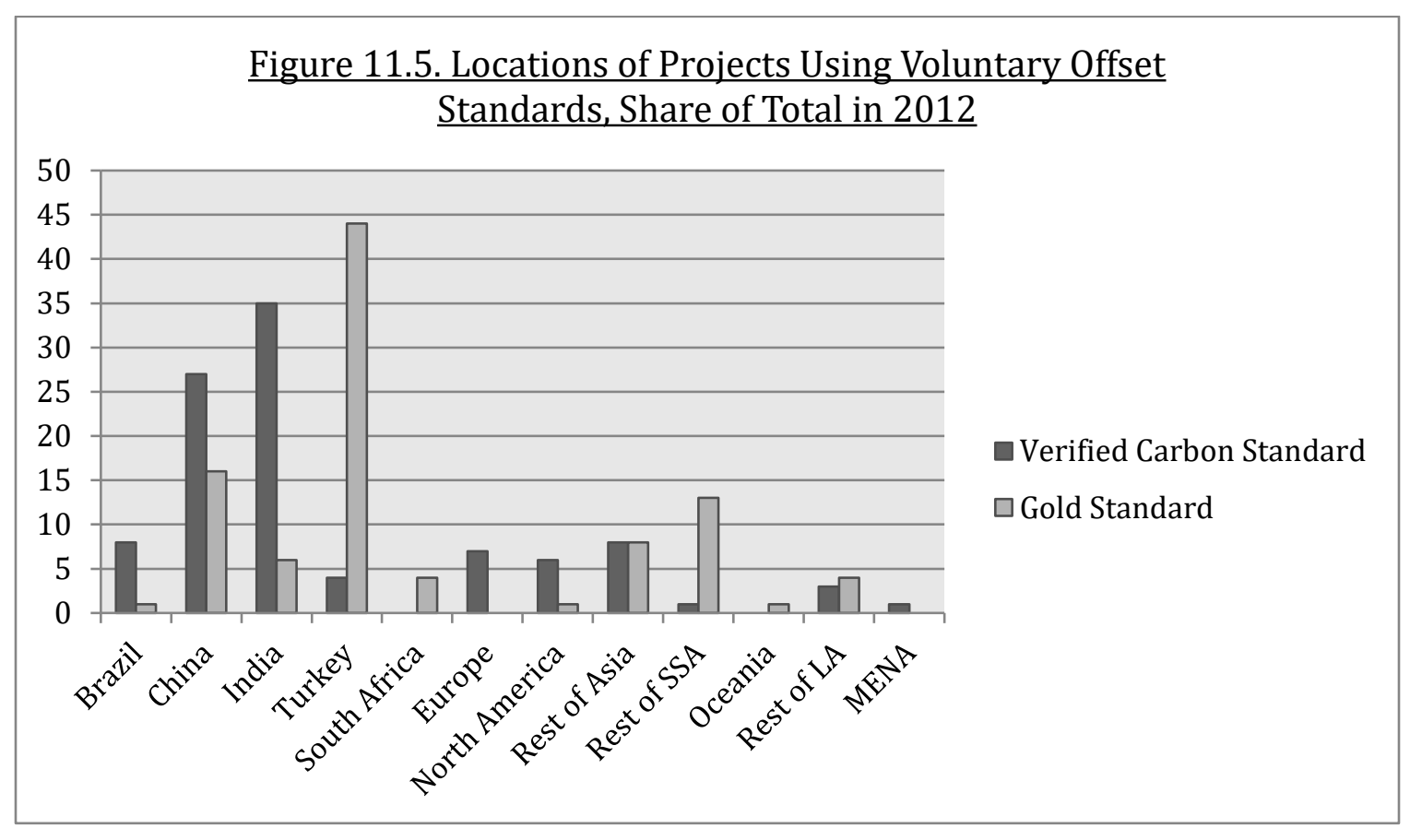




\section{Endnotes}

${ }^{1}$ Thomas Hale and Charles Roger, "Orchestration and Transnational Climate Governance," Review of International Organizations 9, no. 1 (2014): 59-82.

${ }^{2}$ Jos G.J. Olivier,Greet Janssens-Maenhout, Marilena Muntean, and Jeroen A.H.W. Peters. “Trends in global CO2 emissions: 2013 Report.” PBL Netherlands Environmental Assessment Agency, Institute for Environment and Sustainability (IES) of the European Commission's Joint Research Centre (JRC). The Hague. Available at: http://edgar.jrc.ec.europa.eu/news_docs/pbl2013-trends-in-global-co2-emissions-2013-report-1148.pdf

${ }^{3}$ Björn Conrad, "Bureaucratic Land Rush: China’s Administrative Battles in the Arena of Climate Change Policy," Harvard Asia Quarterly 12, no. 1 (Spring 2010): 52-64; David Held, Charles Roger and Eva-Maria Nag, "Editors' Introduction: Climate Governance in the Developing World," in Climate Governance in the Developing World, ed. David Held, Charles Roger and Eva-Maria Nag, (Cambridge: Polity Press, 2013): 1-28.

${ }^{4}$ Climate change resembles other global issue areas in which transnational governance plays an important role, including global health, trade finance and policing. Karin Backstrand, Accountability of Networked Climate Governance: The Rise of Transnational Climate Partnerships, Amsterdam Conference on Earth System Governance (2007); Philipp Pattberg and Johannes Stripple, "Beyond the Public and Private Divide: Remapping Transnational Climate Governance in the 21st Century," International Environmental Agreements: Politics, Law and Economics 8, no. 4 (2008): 367-388; Noah J. Toly, "Transnational Municipal Networks and Climate Politics: From Global Governance to Global Politics," Globalizations 5, no. 3 (2008): 341-356; Liliana B. Andonova, et al, "Transnational Climate Governance," Global Environmental Politics 9, no. 2 (2009): 52-73; Harrriet Bulkeley et al., Transnational Climate 
Change Governance (Cambridge: Cambridge University Press, 2014); Thomas Hale and Charles Roger, "Orchestration and Transnational Climate Governance": and Thomas Hale and David Held, Handbook of Transnational Governance: Institutions and Innovations (Cambridge: Polity, 2011): 12, 15 .

${ }^{5}$ Bjorn Conrad, et al., Beyond a Global Deal: A UN+ Approach to Climate Governance (Berlin: Global Governance 2020, 2011); Thomas Hale, “A Climate Coalition of the Willing,” The Washington Quarterly 34, no. 1 (Winter 2011): 89-101.

${ }^{6}$ Zhang Zhongxiang, "The World Bank's Prototype Carbon Fund and China," East-West Center Working Papers, Environmental Change, Vulnerability and Governance Series, no. 60 (2004);

Gørild M. Heggelund and Inga Fritzen Buan, "China in the Asia-Pacific Partnership: consequences for UN climate change mitigation efforts," International Environmental Agreements 9, no. 3 (2009): 301-317.

${ }^{7}$ Indeed, most transnational governance, in the climate realm and beyond, originates in North America and Europe. Perhaps for this reason, Chinese scholars have yet to widely embrace the topic of transnational governance. Chinese language scholarship on the subject is small compared to other IR topics, and existing literature often seems to conflate global governance with transnational governance.

${ }^{8}$ Helen Milner, Interests, Institutions, and Information (Princeton: Princeton University Press, 1997).

${ }^{9}$ Harriet Bulkeley, et al., Transnational Climate Change Governance: Mathew Hoffmann, Climate Governance at the Crossroads: Experimenting with a Global Response after Kyoto (Oxford: Oxford University Press, 2011); and Hale and Roger, "Orchestration and Transnational Climate Governance.” 
${ }^{10}$ Ralph Espach, Private Environmental Regimes in Developing Countries: Globally Sown, Locally Grown (New York: Palgrave Macmillan, 2009); and Tim Bartley, “Transnational Private Regulation in Practice: The Limits of Forest and Labor Standards Certification in Indonesia," Business and Politics 12, no. 3 (2010): 1-34; Liliana Andonova, "Boomerangs to Partnerships? Explaining State Participation in Transnational Partnerships for Sustainability," Comparative Political Studies 47, no. 3 (March 2014): 481-515.

${ }^{11}$ Hoffmann, Climate Governance at the Crossroads

${ }^{12}$ Despite our best efforts to conduct a comprehensive search, the database is only indicative. It captures only a part of the total universe of TCG initiatives. Successful TCG schemes are likely to be overrepresented in the sample, since they are likely to last longer and attract more attention. Initiatives involving less prominent actors, or actors on the periphery of central climate governance networks, are likely to be underrepresented. This will possibly lead to a bias in the sample towards initiatives created by actors in the global North. Finally, the sample will likely be biased towards initiatives that have been studied and cited before in academic literature, resulting in some degree of path dependence in the selection of cases. Nevertheless, we can be fairly confident that the database selects the cases of transnational governance that weigh most heavily on the politics of climate change even if the actual number of schemes is much larger.

${ }^{13}$ Kenneth Abbott, "The Transnational Regime Complex for Climate Change," Environment and Planning C: Government and Policy 30, no. 4 (2012): 571-590.

${ }^{14}$ http://cdm.unfccc.int/Statistics/Public/files/201409/cers_iss_byHost.pdf; http://cdm.unfccc.int/Statistics/Public/files/201409/proj_reg_byHost.pdf 
${ }^{15}$ For example, China Beijing Environmental Exchange (CBEEX), held a sale in June 2011 for 210,000 tons of carbon to an "honor roll" of customers including Baidu, Air China, Merchants Bank, and China Everbright Bank. Though largely symbolic (the amount of credits was equivalent to 0.002 percent of China's emission that year), the sale represented an important step toward testing and building a domestic carbon market

${ }^{16}$ Anja Kollmuss, Helge Zink, and Clifford Polycarp, Making Sense of the Voluntary Carbon Market, A Comparison of Carbon Offset Standards, (Germany: World Wildlife Fund, 2008).

${ }^{17}$ Michele Betsill and Harriet Bulkeley, "Cities and the Multilevel Governance of Climate Change." Global Governance 12, no. 2 (2006): 141-159.

${ }^{18}$ Ibid.

${ }^{19}$ The City of Shenyang is one of the largest industrial centers in China and has been greatly affected by local and regional air pollution. As a result, it has been at the forefront of municipal efforts to improve air quality in China, for instance, by administering a levy on boilers that effectively serves as a local carbon tax. In attempting to tackle local air pollution, city officials have found that such measures can also serve to mitigate carbon emissions. See ICLEI, Local Government Implementation of Climate Protection: Case Studies (1997), www.iclei.org/index.php?id=1476.

${ }^{20}$ GRI2010, Global Sustainability Reporting Statistics, https://www.globalreporting.org/resourcelibrary/GRI-Reporting-Stats-2010.pdf.

${ }^{21}$ CDP 2011a, Carbon Disclosure Project, Report 2011, China 100 Executive Summary, https://www.cdproject.net/CDPResults/CDP-2011-China-Report-Exec-Summary.pdf; CDP Cities 2011 - Global Report on C40 Cities, 
http://c40citieslive.squarespace.com/storage/CDP\%20Cities\%202011\%20Global\%20Report.pdf;

Eun-Hee Kim and Thomas Lyon, "Carbon Disclosure Project" in Handbook of Transnational

Governance: Institutions and Innovations, ed. Thomas Hale and David Held: 212-218.

${ }^{22}$ Interview with Project Officer, Energy and Climate Registry, Beijing, October 2011.

${ }^{23}$ Interview with Innovation Center for Energy and Transport, Beijing, October 2011.

${ }^{24}$ Interview with Energy and Climate Registry, Beijing, October 2011.

${ }^{25}$ Miriam Schroeder, "The Construction of China's Climate Politics: Transnational

NGOs and the Spiral Model of International Relations," Cambridge Review of

International Affairs 21, no.4 (2008): 505-525.

${ }^{26}$ A study by Prakash and Potoski shows that domestic institutions affect the impact of transnational governance, showing that more stringent domestic environmental laws increased the effectiveness of ISO 14001 on corporate behaviour. Aseem Prakash and Matthew Potoski, "Global Private Regimes, Domestic Public Law: ISO 14001 and Pollution Reduction,"

Comparative Political Studies 47, no. 3 (March 2014): 369-394.

${ }^{27}$ Tim Bartley, "Transnational Private Regulation in Practice: The Limits of Forest and Labor Standards Certification in Indonesia," Business and Politics 12, no.3 (2010): 1-34.

${ }^{28}$ Ralph Espach, Private Environmental Regimes in Developing Countries: Globally Sown, Locally Grown (New York: Palgrave Macmillan, 2009).

${ }^{29}$ Liliana Andonova, "Boomerangs to Partnerships?"

${ }^{30}$ Petra Christmann and Glen Taylor, "Globalization and the Environment: Determiants of Firm Self-regulation in China," Journal of International Business Studies 3, no. 32 (2001): 439-458;

Petra Christmann and Glen Taylor, "Firm Self-Regulation through International Certifiable Standards: Determinants of Symbolic versus Substantive Implementation,” First Annual 
Conference on Institutional Mechanisms for Industry Self-Regulation, Dartmouth University, New Hampshire (2005).

${ }^{31}$ For an overview of this literature see David Graham and Ngaire Woods, "Making Corporate Self-Regulation Effective in Developing Countries," World Development 34, no.5 (2006): 868883; and Simone Pulver, "Introduction: Developing-Country Firms as Agents of Environmental Sustainability?" Studies in International Comparative Development 42 (2007): 191-207.

${ }^{32}$ Daniel Drezner and Mimi Lu, "How Universal are Club Standards? Emerging Markets and Volunteerism." in Voluntary Programs: A Club Theory Perspective, ed. Matthew Potoski and Aseem Prakesh (Cambridge: MIT Press, 2009): 181-206. On the Russian case, see Andonova, "Boomerangs to Partnerships?"

${ }^{33}$ Guobin Yang, "Environmental NGOs and Institutional Dynamics in China," The China Quarterly 181 (2005): 46-66.

${ }^{34}$ Jonathan Schwartz, "Environmental NGOs in China: Roles and Limits," Pacific Affairs 77, no.1 (2004): 28-49; Phillip Stalley and Dongning Yang, “An Emerging Environmental Movement in China?" The China Quarterly, no. 186 (2006): 333-356.

${ }^{35}$ Jonathan Schwartz, "Environmental NGOs in China: Roles and Limits," Pacific Affairs 77, no.1 (2004): 28-49; Yang, "Environmental NGOs and Institutional Dynamics in China"; Stalley and Yang, "An Emerging Environmental Movement in China?”; and Shui-Yan Tang and Xueyong Zhan, "Civic Environmental NGOs, Civil Society, and Democratisation in China," Journal of Development Studies 44, no. 3 (2008): 425-448.

${ }^{36}$ Changxing Di, "ISO 14001: The Severe Challenge for China," in Growing Pains: Environmental Management in Developing Countries, ed. Walter Wehrmeyer and Yacob Mulugetta, (Sheffield: Greenleaf, 1999): 106-116. 
${ }^{37}$ David Vogel, Trading Up: Consumer and Environmental Regulation in a Global Economy (Cambridge, Harvard University Press: 1995); Petra Christmann and Glen Taylor, "Globalization and the Environment: Determiants of Firm Self-regulation in China," Journal of International Business Studies 3, no.32 (2001): 439-458; and Petra Christmann and Glen Taylor, "Firm SelfRegulation through International Certifiable Standards: Determinants of Symbolic versus Substantive Implementation,” First Annual Conference on Institutional Mechanisms for Industry Self-Regulation, Dartmouth University, New Hampshire (2005); Simone Pulver, "Introduction: Developing-Country Firms as Agents of Environmental Sustainability?"

${ }^{38}$ Shu Yi Chu and Heike Schroeder, "Private Governance of Climate Change in Hong Kong: An Analysis of Drivers and Barriers to Corporate Action,” Asian Studies Review 34 (2010), 287308; Lin-Wen Lin, "Corporate Social Responsibility in China: Window Dressing or Structural Change,” Berkeley Journal of International Law 28, no.1 (2010): 64-100.

${ }^{39}$ Kenneth Lieberthal and Michel Oksenberg, Policy Making in China: Leaders, Structures, and Processes, (Princeton: Princeton University Press, 1988).

${ }^{40}$ Andrew Mertha, "Fragmented Authoritarianism 2.0: Political Pluralization in the Chinese Policy Process," China Quarterly 200, (2009): 995-1012; Ka Zeng, China Foreign Trade Policy: The New Constituencies. K. Zeng, (New York: Routledge, 2007); and Scott Kennedy, The Business of Lobbying in China (Cambridge, MA: Harvard University Press, 2005).

${ }^{41}$ Björn Conrad, "Bureaucratic Land Rush: China’s Administrative Battles in the Arena of Climate Change Policy," Harvard Asia Quarterly, 12, no. 1 (Spring 2010): 52; and Hongyuan Yu, "Global Governance against Global Warming and China's Response," Chinese Public Affairs Quarterly 2 no.4 (2010): 296-313; and David Held, Charles Roger and Eva-Maria Nag, “A Green Revolution: China's Governance of Energy and Climate Change" in Climate Governance 
in the Developing World, ed. David Held, Charles Roger and Eva-Maria Nag, (Cambridge: Polity Press, 2013): 29-52.

${ }^{42} \mathrm{Yu}$ interprets this policy coordination as evidence against a fragmented authoritarian model, because the final policy is broadly accepted by the relevant actors, at least at the central level. Here we use the concept somewhat differently, more as a measure of the degree of interest divergence and open contestation present in intra-bureaucratic wrangling. Yu's empirical findings are consistent with this interpretation. Yu, "Global Governance against Global Warming and China's Response."

${ }^{43}$ Elizabeth Economy, The River Runs Black: The Environmental Challenge to China's Future (Ithaca: Cornell University Press, 2004); Benjamin van Rooij, "Implementation of Chinese Environmental Law: Regular Enforcement and Political Campaigns," Development and Change 37, no.1 (2006): 57-74; and Gregory Fuller, "Economic Warlords: How de Facto Federalism Inhibits China's Compliance with International Trade Law and Jeopardizes Global Environmental Initiatives,” Tennessee Law Review, no. 75 (2007): 545-576. Kostka and Hobbs have traced the implementation of climate and energy efficiency policies mandated by the $11^{\text {th }}$ Five Year Plan in Shanxi province. They show how the provincial leaders, eager to achieve stringent energy-saving goals in order to please Beijing, bundled unpopular climate change policies together with generous incentives for local interest groups (such as favorable land-use allocations) to "log-roll" - the authors make explicit the analogy to pluralist political dynamicsinterest groups into supporting climate policies. See Genia Kostka and William Hobbs, "Local Energy Efficiency Policy Implementation in China: Bridging the Gap between National Priorities and Local Interests," The China Quarterly, no. 211 (2012): 765-785.

${ }^{44}$ Miriam Schroeder, “The Construction of China's Climate Politics: Transnational 
NGOs and the Spiral Model of International Relations," Cambridge Review of

International Affairs 21, no. 4 (2008): 505-525.

${ }^{45}$ In this way, climate advocacy has organized along similar lines as business lobbying. See Scott Kennedy, "Transnational Political Alliances: An Exploration with Evidence from China," Business and Society 46, no. 2 (2007): 174-200.

${ }^{46}$ Interview with Zhang Haibin, School of International Studies, Peking University, Beijing, October 2011.

${ }^{47}$ Kenneth W. Abbott and Duncan Snidal, "Strengthening International Regulation through Transnational Governance: Overcoming the Orchestration Deficit," Vanderbilt Journal of Transnational Law 42 (2009): 501-578; Hale and Roger, Orchestration and Transnational Climate Governance.

${ }^{48}$ Hale and Roger, "Orchestration and Transnational Climate Governance." 